\title{
UJI AKTIVITAS ANTIBAKTERI EKSTRAK BUAH PEPINO (Solanum Muricatum Ait) TERHADAP PERTUMBUHAN BAKTERI Esherichia coli
}

\author{
*)Sainal Edi Kamal, *)Desi Lara Tiara \\ *)Akademi Farmasi Sandi Karsa Makassar \\ *)Program Studi D-III Farmasi Sandi Karsa Makassar
}

\begin{abstract}
ABSTRAK
Penelitian ini adalah jenis penelitian eksperimen. Tujuan penelitian ini adalah untuk menentukan uji aktivitas antibakteri ekstrak Buah Pepino (Solanum muricatum Ait) terhadap pertumbuhan bakteri Escherichia coli yang ditunjukkan oleh pembentukkan zona hambatatau zona bening pada media pertumbuhan bakteri uji. Penelitian inidi laksanakan di Laboratorium Biologi Akademi Farmasi Sandi Karsa Makassar pada bulan Maret 2019 dengan menggunakan metode maserasi, 3 replika dan 3 konsentrasi yaitu 5\%, 10\% dan 15\%. Hasil penelitian ini menunjukkan bahwa ekstrak Buah Pepino (Solanum muricatum) pada konsentrasi 5\% dengan zona hambat sebesar $11,3 \mathrm{~mm}, 10 \%$ dengan zona hambat sebesar $11,5 \mathrm{~mm}$ dan $15 \%$ dengan zona hambat sebesar $11,7 \mathrm{~mm}$ dengan zona hambat optimum yaitu pada konsentrasi $15 \%$ dengan zona hambat $11,7 \mathrm{~mm}$.
\end{abstract}

Kata kunci : Ekstrasi, Solanum muricatum Ait, Escherichia coli.

\section{PENDAHULUAN}

\section{A. Latar Belakang}

Masyarakat Indonesia mulai mengutamakan penggunaan obat secara alami. Sebelum obat-obat kimia berkembang secara modern, nenek moyang kitaumumnya menggunakan obat-obatan yang berasal dari tumbuh-tumbuhan untukmengatasi masalah kesehatannya. Tumbuhan obat yang digunakan olehmasyarakat mempunyai kelebihan yaitu memiliki efek samping yang kecildibandingkan dengan pengobatan kimiawi (Kardinan dan Taryono, 2003).

Diare dapat disebabkan oleh infeksi maupun non infeksi. Diare yang terbanyak adalah diare yang disebabkan oleh infeksi kuman pathogen baik dari jenis virus, bakteri maupun parasit. Beberapa bakteri berikut ini dapat menyebabkan terjadinya diare yaitu: Staphylococcus aureus, Bacillus cereus, Clostridium perferingens, Escherichia coli, Vibrio cholerae, Shigella sp, Salmonella sp, Clostridium difficile, Campylobacter jejuni, Yersinia enterolitica, Klebsiella pnemoniae, Vibrio haemolyticus.

Escherichia colitermasuk ke dalam salah satu bakteri yang dapat menyebabkan diare yang umum dijumpai dalam perairan sebagai indikator air tercemar. Escherichia coli dapat masuk ke dalam tubuh manusia melalui konsumsi air maupun makanan berupa daging, susu mentah serta produk susu. Escherichia coli merupakan flora normal saluran pencernaan (Hening. 2013). Akan tetapi mempunyai potensi menimbulkan penyakit dalam keadaan yang cocok. Escherichia coli menjadi patogen jika jumlah bakteri ini dalam saluran pencernaan meningkat atau berada diluar dan menghasilkan enterotoksin yang dapat menyebabkan diare (Volk \& Wheeler, 1989).

Tanaman Pepino mulai dikenal di Indonesia pada akhir tahun 2000. Tanaman ini dikenal dengan berbagai nama antara lain melodi, puspita, merong, husada dewa, cabai manis, timun manis, dan lainlain. Di Indonesia, tanaman ini mula-mula ditemukan di daerah Dieng sehingga disebut Melon Dieng, disingkat Melodi. Tanaman ini disebut Husada Dewa karena khasiatnya sebagai obat, salah satunya diare. Bagian Pepino yang paling sering digunakan adalah daging Buah Pepino. Buah Pepino kaya akan antioksidan beta-karoten yang dapat mencegah segala macam penyakit. Kandungan seratnya yang tinggi dan alami yang ada pada buah Pepino sangatlah ampuh dalam mengatasi beragam penyakit seperti wasir, sembelit, serta beragam gangguan pencernaan yang lain (Mitra,2005).

Didaerah Mangkutana Kabupaten Luwu Timur biasanya masyarakat menggunakan Buah Pepino sebagai tanaman hias karena belum mengetahui khasiat yang terkandung dalam Buah Pepino, sedangkan didaerah Malino masyarakat menggunakan Buah Pepino sebagai pengobatan alami untuk mengobati penyakit salah satunya diare, maka tidak heran di daerah dataran tinggi ini banyak masyarakat yang ingin mengkonsumsinya. Berdasarkan uraian diatas, maka peneliti tertarik untuk melakukan penelitian uji aktivitas antibakteri ektrak Buah Pepino (Solanum muricatum Ait) terhadap Escherichia coli dapat bersifat antibakteri.

\section{B. Rumusan Masalah}

Rumusan masalah pada penelitian ini adalah bagaimanakah hasil uji aktivitas antibakteri ekstrak 
Buah Pepino (Solanum muricatum Ait) terhadap pertumbuhan Escherichia coli?

\section{Tujuan Penelitian}

Penelitian ini bertujuan untuk menentukan uji aktivitas antibakteri ekstrak Buah Pepino (Solanum muricatum Ait) terhadap pertumbuhan Escherichia coli.

\section{Manfaat Penelitian}

Hasil penelitian ini diharapkan dapat memberikan informasi dan menambah ilmu pengetahuan aktivitas antibakteri ekstrak Buah Pepino (Solanum muricatum Ait) terhadap pertumbuhan Escherichia coli.

\section{METODE PENELITIAN}

\section{A. Jenis Penelitian}

Jenis penelitian ini merupakan penelitian eksperimen laboratorium dengan melakukan penelitian untuk mengetahui uji aktivitas antibakteri ekstrak buah Pepino (Solanum muricatum Ait) terhadap bakteri Escherichia coli.

\section{B. Waktu Dan Tempat Penelitian}

Penelitian ini dilaksanakan pada bulan Maret 2019 di Laboratorium Biologi Akademi Farmasi Sandi Karsa Makassar.

\section{Alat Dan Bahan}

Alat yang digunakan yaitu Autoclaf (Medicaloxigen Gauge), Batang pengaduk, Cawan petri, Erlenmeyer (Approx), Gelas kimia (Approx), Gelas ukur (Pirex), LAF (Heles), Inkubator (Wina instrument), Jangka sorong, Osebulat, Pinset, Separangkat alat maserasi, Rak tabung, Sendok tanduk, Spoit 3ml, Tabung reaksi (Pirex), Timbangan analitik (QBB).

Bahan yang digunakan yaitu Air suling $\left(\mathrm{H}_{2} \mathrm{O}\right)$, Alkohol 70\%, Aluminium foil, Biakan murni Escherichia coli, Ciprofloxacin, Kain kassa steril, Kertas label, Larutan $\mathrm{NaCl}$ 0,9\%, Masker, Medium NA (Nutrient Agar), Na.CMC, Paper disk, Plastik Wrap, Tanaman Sawo manila (Manilkara zapota L.) sebagai sampel.

\section{Tempat Pengambilan Sampel}

Sampel Buah Pepino (Solanum muricatum Ait), di ambil di Malino Desa Pattapang Kecamatan Tinggimoncong Kabupaten Gowa.

\section{E. Desain Penelitian}

a. Cara strerilisasi Alat

Alat-alat yang digunakan disterilkan dahulu. Alat-alat dari gelas dicuci dengan deterjen kemudian dibilas dengan air bersih, selanjutnya dibilas menggunakan alcohol $70 \%$ kemudian dicuci hingga bersih dengan air suling lalu dikeringkan diudara terbuka. Setelah itu disterilkan menggunakan autoklaf pada suhu $121^{\circ} \mathrm{C}$ selama 15 menit. Sedangkan untuk pinset dan ose disterilkan dengan cara pemijaran dengan api langsung.

b. Penyiapan Bahan

\section{Pengambilan Sampel}

Sampel yang digunakan adalah buah Pepino dan diperoleh di Malino. Bagian tanaman yang diambil adalah daging buah Pepino yang sudah matang. Sampel dicuci dengan air yang mengalir kemudian dikupas kulitnya, lalu dirajang dan selanjutnya dijemur pada tempat yang tidak terkena sinar matahari langsung atau diangin-anginkan. Daging buah Pepino yang telah keringditimbang sebanyak 500g.

2. Pembuatan ekstrak buah Pepino

Daging buah Pepino yang sudah kering ditimbang $500 \mathrm{~g}$ dimasukkan dalam bejana kemudian ditambahkan dengan pelarut Etanol 96\% hingga terendam menutupi permukaan simplisia dan ditutup rapat, dimaserasi selama 3 hari ditempat yang terlindung dari sinar matahari. Dan setiap 24 jam dilakukan pengadukan, setelah 3 hari disaring dan dipisahkan ampas dan filtratnya. Ekstrak cair Etanol yang diperoleh diuapkan di Rotavafor hingga didapatkan ekstrak kental, ekstrak kental kemudian pekatkan di atas water bath.

3. Pembuatan Bahan Uji

Pada pembuatan bahan uji dibuat dalam kosentrasi $5 \%$ b/v, $10 \%$ b/v dan $15 \% \mathrm{~b} / \mathrm{vdengan}$ cara di timbang masingmasing kosentrasi lalu dimasukkan kedalam Erlenmeyer kemudian dilarutkan dengan aquadest.

4. Pembuatan Medium Nutrient Agar (NA) Komposisi :

$\begin{array}{ll}\text { Lab lemco powder } & : 1,0 \text { gram } \\ \text { Yeast extract } & : 2,0 \text { gram } \\ \text { Pepton } & : 5,0 \text { gram } \\ \text { Sodium chloride } & : 5,0 \text { gram } \\ \text { Agar } & : 15,0 \text { gram } \\ \text { Air suling hingga } & : 1000 \mathrm{ml}\end{array}$

Cara pembuatan :

Ditimbang medium NA sebanyak 2,8gram, dimasukkan kedalam Erlenmeyer kemudian dilarutkan dengan air suling hingga $100 \mathrm{ml}$ dihomogenkan dan dipanaskan di hot plate sambal diaduk hingga larutan mendidih, kemudian ditutup dengan aluminium foil. Setelah itu disterilkan dalam autoklaf pada suhu $121^{\circ} \mathrm{C}$ selama 15 menit.

5. Peremajaan Bakteri 
Bakteri Escherichia coli yang berasal dari biakan murni, diambil 1 ose pada bakteri, kemudian diinkubasi dengan cara digores pada medium Nutrien Agar (NA) miring dan diinkubasi pada suhu $37^{\circ} \mathrm{C}$ selama 24 jam secara steril didalam Laminar Air Flow (LAF) sehingga diperoleh bakteri murni.

6. Pembuatan Suspensi Bakteri

Bakteri uji hasil peremajaan selanjutnya diambil 1 ose kemudian disuspensikan kedalam tabung reaksi yang berisi $10 \mathrm{ml} \mathrm{NaCl} 0,9 \%$ steril, kemudian dihomogenkan.

7. Pembuatan larutan pembanding

Larutan kontrol positif menggunakan Diapet kapsul. Diapet dilarutkan terlebih dahulu dengan aquadest $100 \mathrm{ml}$, sedangkan kontrol negatif digunakan aquadest.

c. Pengujian Uji aktivitas antibakteri buah Pepino

1. Disiapkan medium NA dan alat yang steril

2. Diambil medium NA sekitar $20 \mathrm{ml}$ dan dimasukkan dalam cawan petri steril lalu dibiarkan memadat.

3. Setelah memadat ditambahkan suspense Escherichia coli $0,5 \mathrm{ml}$ pada cawan petri.

4. Disiapkan 5 paper disk dan dimasukkan kedalam masing-masing erlenmeyer (kosentrasi 5\%, 10\%, 15\%, kontrol positif dan kontrol negatif).

5. Ditempatkan paper disk secara diagonal pada permukaan medium tersebut.

6. Cawan petri kemudian diinkubasi pada suhu $37^{\circ} \mathrm{C}$ selama $1 \times 24$ jam.

d. Pengamatan dan pengukuran diameter hambatan

Pengamatan dan pengukuran diameter hambatan dilakukan dengan menggunakan jangka sorong setelah diinkubasi pada suhu $37^{\circ} \mathrm{C}$ selama $1 \times 24$ jam.

e. Pengelolaan Data Analisis Data

Data yang telah diperoleh kemudian dikumpul. Data berupa diameter daerah hambatan, dianalisis dengan menggunakan metode rancangan acak lengkap dan dilajutkan dengan uji beda nyata terkecil untuk melihat pengaruh ekstrak buah Pepino terhadap daerah hambatan pertumbuhan mikroba uji yang dihasilkan.

\section{HASIL PENELITIAN DAN PEMBAHASAN}

\section{A. Hasil Penelitian}

Hasil uji aktivitas antibakteri ekstrak buah Pepino (Solanum muricatum Ait) terhadap pertumbuhan bakteri Escherichia coli menunjukkan adanya aktivitas antibakteri. Hal ini dapat dilihat dari diameter zona hambat yang terbentuk yaitu berupa wilayah jernih disekeliling paper disk yang mengandung ekstrak buah pepino dalam konsentrasi $5 \%, 10 \%$ dan $15 \%$.

Hasil pengukuran diameter zona hambat ekstrak buah Pepino (Solanum muricatum Ait) terhadap pertumbuhan bakteri Escherichia coli dapat dilihat pada Tabel di bawah ini.

Tabel I. Hasil pengukuran diameter zona hambat ekstrak buah Pepino (Solanum muricatum Ait).

\begin{tabular}{|c|c|c|c|c|}
\hline \multirow[t]{2}{*}{ Kosentrasi } & \multicolumn{3}{|c|}{ Perlakuan (mm) } & \multirow{2}{*}{$\begin{array}{c}\text { Rata-rata } \\
(\mathbf{m m})\end{array}$} \\
\hline & 1 & 2 & 3 & \\
\hline Kosentrasi 5\% & 11,55 & 11 & 11,45 & 11,33 \\
\hline Kosentrasi $10 \%$ & 11,45 & 11,65 & 11,65 & 11,58 \\
\hline Kosentrasi $15 \%$ & 11,66 & 11,83 & 11,93 & 11,80 \\
\hline Kontrol (+) & 11,63 & 11,83 & 11,98 & 11,81 \\
\hline Kontrol (-) & 0 & 0 & 0 & 0 \\
\hline
\end{tabular}

\section{B. Pembahasan}

Data dalam tabel I. Didapatkan bahwa pemberian ekstrak buah Pepino dengan kosentrasi berbeda memiliki daya hambat yang berbeda pula terhadap pertumbuhan Escherichia coli. Pada ekstrak buah pepino konsentrasi 5\% didapatkan nilai rata-rata $11,33 \mathrm{~mm}$, pada ekstrak buah pepino $10 \%$ didapatkan nilai rata-rata $11,58 \mathrm{~mm}$, pada ekstrak buah pepino konsentrasi $15 \%$ didapatkan nilai rata-rata $11,80 \mathrm{~mm}$, nilai rata-rata Diapet didapatkan nilai rata-rata $11,81 \mathrm{~mm}$ dan hasil ratarata dari kontrol negatif menggunakan aquadest ialah $0 \mathrm{~mm}$ atau tidak terbentuk zona hambat. Hasil ini menunjukkan bahwa semakin besar konsentrasi ekstrak buah pepino maka zona hambat yang terbentuk juga akan semakin besar.

Untuk melihat kemampuan suatu tanaman dalam menghambat pertumbuhan mikroorganisme maka diukur hambatannya setelah diinkubasi. Zona hambatan adalah daerah bening yang tidak ditumbuhi oleh mikroorganisme disekitar paper disk karena pengaruh suhu bahan atau zat yang bersifat antibakteri. Zona bening di media pertumbuhan terjadi karena antibakteriakan mengakibatkan pembentukkan cincin-cincin hambatan didalam area pertumbuhan bakteri yang padat sehingga tidak ada bakteri yang tumbuh didalam cincin tersebut. Keampuhan suatu antibakteri dapat dilihat dari seberapa besar zona bening yang terbentuk akibat berdifusinya zat antibakteri tersebut.

Zona hambat yang terbentuk pada paper disk yang berisi ekstrak buah Pepino menunjukkan bahwa efek antibakteri dari ekstrak buah Pepino memiliki daya hambat. Berdasarkan penelitian Davis dan Stout pada tahun 1971 penentuan zona hambat dapat dilihat dari hasil pengukuran diameter yang digolongkan menjadi (1) tidak ada zona hambat, (2) lemah yaitu zona hambat kurang dari 5 
$\mathrm{mm}$, (3) sedang yaitu zona hambat 5-10 mm, (4) kuat yaitu zona hambat 11-20 mm, dan (5) sangat kuat yaitu zona hambat 21-30 mm. Berdasarkan kriteria davis dan stout, ekstrak buah pepino pada setiap kosentrasi yaitu kosentrasi 5\%, 10\%, dan $15 \%$ pada Esherichia colidapat dikategorikan daya hambat kuat karena nilai-nilai dari setiap kisaran berada pada kisaran 11-20 mm. pada uji kontrol positif yang menggunakan antidiare Diapet memiliki daya hambat sangat kuat. Pada uji negatif yang menggunakan aquadest tidak terbentuk zona hambat yang menunjukkan bahwa aquadest tidak memiliki efek antibakteri.

Hasil pengukuran diameter zona hambatan memperlihatkan terjadinya peningkatan diameter zona hambatan seiring dengan kenaikan kosentrasi yang tidak berbeda nyata atau non-signifikan. Berdasarkan hasil analisis data dengan menggunakan metode Rancangan Acak Lengkap (RAL) diperoleh hasil yang signifikan antara masing-masing konsentrasi ekstrak. Hal ini dapat dilihat dari nilai $\mathrm{F}$ hitung (23) lebih besar dari $\mathrm{F}$ tabel pada taraf 5\% (2,30) dan taraf 1\% $(3,35)$. Pada analisis lanjutan dengan metode Beda Nyata Terkecil diperoleh hasil yang non signifikan pada taraf 5\% dan taraf $1 \%$ pada semua konsentrasi ekstrak 5\%, 10\% dan 15\% yang berarti peningkatan diameter zona hambatan seiring dengan kenaikan kosentrasi terjadi namun memiliki hasil yang tidak berbeda nyata. Kenaikan konsentrasi ekstrak buah Pepino berpengaruh terhadap pertumbuhan bakteri, dimana ekstrak $15 \%$ diameter zona hambatnya lebih besar karena pada penelitian ini semakin besar konsentrasi ekstrak yang digunakan maka semakin besar pula senyawa atau zat aktif yang terdapat di dalam ekstrak buah Pepino yang berefek sebagai antibakteri.Faktor-faktor yang mempengaruhi besarnya daerah hambatan untuk masing-masing konsentrasi yaitu kandungan zat aktif dalam tiap paper disk, kepekaan pertumbuhan bakteri, ketebalan medium, viskositas medium dan temperatur inkubasi.

Hasil pengamatan daerah hambatan yang dilakukan pada masa inkubasi 1 x 24 jam terjadi perubahan terhadap daerah bening yang terbentuk yaitu dari daerah yang bening menjadi daerah yang keruh, berarti ekstrak buah Pepino bersifat bakteriostatik. Hal ini sesuai dengan pendapat wattimena (1991) yang menyatakan bahwa bila daerah hambatan yang terjadi tetap bening setelah 24 jam, menunjukkan bahwa antimikroba yang digunakan adalah bakterisid yang artinya senyawa dapat membunuh bakteri, sedangkan bila selama 24 jam masa inkubasi daerah hambatan bening kemudian menjadi keruh setelah masa inkubasi menunjukkan bahwa antimikroba tersebut bersifat bakteriostatik.

\section{PENUTUP}

\section{A. Kesimpulan}

Kesimpulan dari hasil penelitian ini adalah bahwa Ekstrak buah Pepino (Solanum muricatum Ait) pada konsentrasi $15 \%$ mempunyai aktivitas antibakteri yang bersifat bakteriostatik terhadap pertumbuhan Escherichia coli.

\section{B. Saran}

1. Perlu dilakukan penelitian lebih lanjut dengan menggunakan bakteri yang berbeda.

2. Perlu dikembangkan dengan memformulasikan suatu sediaan dari ekstrak buah Pepino yang berkhasiat sebagai antibakteri.

\section{DAFTAR PUSTAKA}

Agro mitra, melodi. 2005. Pepino buah mewah berkhasiat obat. Kanisius: Yogyakarta.

Dalimartha, Setiawan. 2006. Solanum muricatum. Jakarta : Niaga Swadaya.

Ibrahim, Sanusi. 2013. Teknik Laboratorium Kimia Organic. Yogyakarta : Graha Ilmu

Ikmalia.2008. Analisa profil protein isolate Escherichia coli SI hasil iradiasi sinar gamma (skripsi). Jakarta : Fakultas sains dan teknologi Universitas Islam Negeri Syarif Hidayatullah Jakarta.

Jawetz, E., Menick, J \& Adelberg, E. A. 2001. Mikrobiologi Kedokteran Edisi I. Jakarta: Salemba Medika

Mukhrian. 2014. Ekstraksi, Pemisahan Senyawa, Dan Identifikasi Senyawa Aktif. Jurnal Kesehatan. Fakultas Ilmu Kesehatan UIN Alauddin Makassar. Volume VII No.2

Volk, Wesley A dan Margaret F Wheeler. 1989. Mikrobiologi Dasar Jilid 2. Jakarta: Erlangga 